\title{
Age influences the effects of nicotine and monoamine oxidase inhibition on mood-related behaviors in rats
}

\author{
Anne-Sophie Villégier • Brittney Gallager • Jon Heston • \\ James D. Belluzzi • Frances M. Leslie
}

Received: 22 July 2009/Accepted: 14 December 2009/Published online: 14 January 2010

(C) The Author(s) 2010. This article is published with open access at Springerlink.com

\begin{abstract}
Rationale Epidemiological studies have demonstrated a comorbidity of smoking with depression and anxiety, particularly during adolescence. However, few animal studies have considered possible synergistic interactions between nicotine and other tobacco smoke constituents, such as monoamine oxidase (MAO) inhibitors, in the regulation of mood.

Objectives The aim of the study was to test the hypothesis that nicotine combined with the irreversible MAO inhibitor, tranylcypromine, will differentially affect depression- and anxiety-related behaviors in adolescent and adult rats.

Methods Nicotine $(0,0.05,0.2 \mathrm{mg} / \mathrm{kg}$, s.c.) and tranylcypromine $(3 \mathrm{mg} / \mathrm{kg}$, i.p.) were tested separately, or together, on male rats aged postnatal days 30 and 68 , in three moodrelated behavioral tests: forced swim test (FST), elevated plus maze (EPM), and open field.

Results Nicotine $(0.2 \mathrm{mg} / \mathrm{kg})$ in adults significantly decreased floating time in the FST and increased time spent in the open arm of the EPM, with no change in locomotor
\end{abstract}

A.-S. Villégier · B. Gallager · J. Heston · J. D. Belluzzi •

F. M. Leslie

Department of Pharmacology, School of Medicine,

University of California,

Irvine, CA 92697, USA

F. M. Leslie

Department of Anatomy and Neurobiology, School of Medicine,

University of California,

Irvine, CA 92697, USA

A.-S. Villégier $(\bowtie)$

Unité de Toxicologie Expérimentale, Institut National de

l'Environnement Industriel et des Risques (INERIS),

Parc Technologique ALATA, BP no. 2,

60550 Verneuil-en-Halatte, France

e-mail: anne-sophie.villegier@ineris.fr activity. Tranylcypromine pretreatment combined with nicotine $(0.2 \mathrm{mg} / \mathrm{kg})$ significantly increased locomotor activity and time spent in the center of the open field. Whereas nicotine alone had no significant effect on adolescents, it significantly increased locomotor activity and decreased floating time in the FST when combined with tranylcypromine pretreatment.

Conclusions There is an age-dependent effect of nicotine, alone and in combination with MAO inhibition, on moodrelated behaviors. Whereas nicotine alone induces mood improvement in adults, it has no effect on adolescents. Nicotine combined with tranylcypromine has unique, agedependent effects. Thus, experimental studies of smoking should consider both age and other tobacco constituents, such as MAO inhibitors, as critical factors.

Keywords Nicotine - Tranylcypromine - Depression · Anxiety $\cdot$ Locomotor activity

$\begin{array}{ll}\text { Abbreviations } \\ \text { EPM } & \text { Elevated plus maze } \\ \text { FST } & \text { Forced swim test } \\ \text { MAO } & \text { Monoamine oxidase } \\ \text { P } & \text { Postnatal day }\end{array}$

\section{Introduction}

Tobacco is one of the most abused reinforcing agents in humans (Balfour et al. 2000). Beside tobacco-induced physical dependence, most smokers report that key motives for smoking include alleviation of negative moods such as anxiety, sadness, and stress (Spielberger and Jacobs 1982; Shiffman 1993). There is considerable evidence that 
smoking is more prevalent in depressed people (46\%) and people with major anxiety disorders than in the general population (26\%; Lasser et al. 2000; Morris et al. 2006). The link between psychiatric disorders and tobacco smoking seems even stronger in adolescents as young adults are at high risk for vulnerability to both serious mental illness and cigarette smoking (Laviola et al. 2003; Breslau et al. 2004; Slawecki et al. 2005; Snyder 2006). Teenagers with depressive disorders are 4.6 times more prone to smoking than teenagers without a depressive disorder (Fergusson et al. 1996). These observations have led several authors to hypothesize that tobacco compounds may improve mood state (Khantzian 1997; Poirier et al. 2002; Upadhyaya et al. 2002).

In order to assess this hypothesis, several studies have tested nicotine on animal models of depression and anxiety in behavioral paradigms that assess mood-related behavior (File et al. 1998; Tizabi et al. 1999; Irvine et al. 1999; Ouagazzal et al. 1999; Cheeta et al. 2000; Vazquez-Palacios et al. 2004, 2005). Whereas nicotine may affect mood (Salin-Pascual and Drucker-Colin 1998), other tobacco constituents may also be involved in this phenomenon. To date, over 4,000 compounds have been identified in tobacco smoke (Report 1989), some of which are known to inhibit monoamine oxidase (MAO). MAO is a mitochondrial enzyme responsible for the breakdown of monoamines. Two forms of the enzyme, MAO A and B, are synthesized by two distinct genes (Shih 2004). Chronic smoking has been shown to irreversibly inhibit MAO by $40 \%$ to $50 \%$ (Fowler et al. 1996a, b, 2003), which may play an important role to elevate mood and may explain the high prevalence of smokers among people with major depression (Fowler et al. 1996a).

The aim of the present study was to test the hypothesis that two components of tobacco smoke, nicotine and MAO inhibitors, can affect mood-related behaviors when tested separately or in combination. Our protocol was designed so that behavioral tests with nicotine were done when MAO activity is inhibited, as in smokers. Tranylcypromine is an irreversible MAO A and B inhibitor sometimes used as an antidepressant in humans. In the present study, tranylcypromine was used acutely to reduce MAO activity, although our aim was not to cause antidepressant effects. It was injected $20 \mathrm{~h}$ prior to nicotine administration to avoid its immediate monoamine-releasing effect that could influence behavioral responses measured soon after injection (Baker et al. 1992). Under these conditions, a tranylcypromine $(3 \mathrm{mg} / \mathrm{kg}$, i.p.) pretreatment decreases MAO activity by $70 \%$ to $80 \%$ in the rat brain and induces a significant increase of nicotine-induced reward (Villégier et al. 2007). This protocol, which has been developed in our laboratory to model the effects of smoking, has the advantage of combining two effects of tobacco smoke,
MAO inhibition and nicotine administration. We believe that this treatment more accurately models cigarette smoking than nicotine administration alone.

Our aim was to determine whether MAO inhibition influenced the effects of nicotine on mood-related behaviors, as well as its rewarding properties. To do so, three paradigms were used to assess emotional behaviors: (1) the forced swim test (FST) to measure the floating time commonly considered as "behavioral despair", a depression-related behavior, (2) the elevated plus maze (EPM) to assess anxiety-related behavior, and (3) the open field to test inhibition of exploratory behavior, measured using the percentage of time spent in the central arena and total locomotion (Prut and Belzung 2003). As adolescence is described as a key period for initiation of tobacco consumption, we tested rats at two different ages, postnatal days (P) 30 and 68, to examine whether nicotine and MAO inhibitor effects on depressive- and anxiety-like behavior would vary according to age.

\section{Materials and methods}

Animals

Male Sprague-Dawley rats were obtained from Charles River at P22 and P60. Animals were housed in groups of four and maintained on a 12-h light/dark cycle (lights on at 07:00 a.m.) with food and water available ad libitum. Rats were allowed at least 1 week of acclimation to the vivarium environment after their arrival, before any treatments began. All tests were performed during the light part of the light-dark cycle. The animals used in this study were housed in an Association for Assessment and Accreditation of Laboratory Animal Care-accredited vivarium maintained by University of California (UC) Irvine University Laboratory Animal Resources personnel. All experimental procedures were performed in compliance with National Institutes of Health (NIH) Guide for Care and Use of Laboratory Animals (NIH no. 85-23, rev. 1985) and approved by the UC Irvine Institutional Animal Care and Use Committee. All efforts were made to minimize animal suffering and to reduce the number of animals used.

Forced swim test

Adolescent and adult rats were subjected to the FST ( $n=$ 113), according to the method previously described (Porsolt et al. 1977). Rats were weighed and handled for 3 days, receiving saline injections on the third day. On day 4 (pretest), each rat, aged P29 or P67, was placed in a glass cylinder (54 cm in height and $24 \mathrm{~cm}$ in diameter) filled with 
water to a depth of $40 \mathrm{~cm}\left(23-25^{\circ} \mathrm{C}\right)$ and allowed to swim for $15 \mathrm{~min}$. Animals were then removed from the cylinder, dried, and returned to their home cages. Pretreatment injections of tranylcypromine ( $3 \mathrm{mg} / \mathrm{kg}$, i.p.) or saline $(1.5 \mathrm{ml} / \mathrm{kg}$, i.p.) were given $20 \mathrm{~h}$ prior to the FST, and the following day, injections of nicotine $(0.05,0.2 \mathrm{mg} / \mathrm{kg}$, s.c. $)$ or saline $(0.75 \mathrm{ml} / \mathrm{kg}$, s.c. $)$ were given $10 \mathrm{~min}$ prior to the FST. On day 5 (test), rats were allowed to swim in the glass cylinders for $5 \mathrm{~min}$. All test sessions were recorded by a video camera from the top of the cylinder. Duration of rat's floating, climbing, and swimming in the water was scored from videotapes by a trained observer who was blinded to the experimental conditions. Floating was defined as the state in which rats were judged to be making only the movements necessary to keep their head above the surface.

\section{Elevated plus maze}

Adolescent and adult rats were subjected to a test in the EPM $(n=98)$, according to a method previously described (Daniels et al. 2004). Rats were weighed and handled for 3 days, receiving saline injections $(1.5 \mathrm{ml} / \mathrm{kg}$, i.p. $)$ on the third day. Injections of tranylcypromine $(3 \mathrm{mg} / \mathrm{kg}$, i.p.) and saline $(1.5 \mathrm{ml} / \mathrm{kg}$, i.p. $)$ pretreatments were given $20 \mathrm{~h}$ prior to the test, with injections of nicotine $(0.05,0.2 \mathrm{mg} / \mathrm{kg}$, s.c.) or saline $(0.75 \mathrm{ml} / \mathrm{kg}$, s.c.) being given $10 \mathrm{~min}$ prior. On day 4 (test), adolescent and adult rats were subjected to behavioral assessment in an EPM. The EPM consists in a plus-shaped acryl maze with two opposite open arms (50 $\mathrm{cm}$ in length and $10 \mathrm{~cm}$ in width) and two opposite closed arms $(50 \mathrm{~cm}$ in length, $10 \mathrm{~cm}$ width, and $31 \mathrm{~cm}$ in height), extending out from a central platform $(10 \times 10 \mathrm{~cm})$. The whole apparatus was elevated $50 \mathrm{~cm}$ above the floor. Each rat was placed in the center of the maze and then allowed to explore the open or closed arms of the maze for $5 \mathrm{~min}$. The time spent in the different arms was recorded. Two paws had to be inside the entrance line to each arm, which signaled the start of the time spent in the specific arm, and then the end time was recorded when all four paws were outside the line again. The maze was cleaned with $70 \%$ ethanol after each test to prevent influences of previously tested rat.

Ambulatory activity and center time

Adolescent and adult rats were subjected to a test in the open field ( $n=62)$, according to the method previously described (Prut and Belzung 2003). Rats were weighed and handled for 3 days, receiving saline injections $(1.5 \mathrm{ml} / \mathrm{kg}$, i.p.) on the third day. Injections of the tranylcypromine (3 $\mathrm{mg} / \mathrm{kg}$, i.p.) and saline $(1.5 \mathrm{ml} / \mathrm{kg}$, i.p.) pretreatments were scheduled $20 \mathrm{~h}$ prior to the test, and injections of nicotine $(0.2 \mathrm{mg} / \mathrm{kg}$, s.c. $)$ or saline $(0.75 \mathrm{ml} / \mathrm{kg}$, s.c. $)$ were performed immediately prior to the test. On day 4 (test), adolescent and adult rats were placed into the middle of a well-illuminated locomotion box immediately after drug injection. Locomotor activity was measured for $30 \mathrm{~min}$ using an open-field activity system measuring $43.2 \times 43.2 \times$ $30.5 \mathrm{~cm}$ (MED Associates, Inc., St. Albans, VT, USA). Horizontal movement was monitored by 16 evenly spaced infrared beams located along two adjacent sides of the chamber. The time spent in the center area of the apparatus, considered as a model of stress-induced inhibition of exploratory behavior, was monitored simultaneously.

\section{Materials}

Drugs (-)-Nicotine hydrogen tartrate and tranylcypromine hydrochloride were purchased from Sigma-Aldrich. Doses are expressed as salts, except for nicotine which is expressed as base. The products were dissolved in saline ( $\mathrm{NaCl}, 0.9 \%$ ) with $\mathrm{pH}$ adjusted to 7.4 with $\mathrm{NaOH}$.

\section{Statistics}

Results presented are means \pm SEM of data obtained with seven to 11 animals per group. Data were analyzed using four-way ANOVA (for pretreatment $\times$ treatment $\times$ age $\times$ time interaction), three-way ANOVA (for pretreatment $\times$ treatment $\times$ age interaction, pretreatment $\times$ treatment $\times$ time interaction or treatment $\times$ age $\times$ time interaction with repeated measures on time), two-way ANOVA (for pretreatment $\times$ treatment interaction, treatment $\times$ age interaction or treatment $\times$ time interaction with repeated measures on time), and one-way ANOVA (for pretreatment, treatment, age, and time effect). Significant effects were tested separately with ANOVAs and Bonferroni- or Dunnett-corrected post hoc comparisons. Time was treated as within-subject factors, and pharmacological treatments and age were analyzed as between-subjects factors. All statistical analyses were performed using SYSTAT 10 statistical software. Statistical significance was set at $p<0.05$.

\section{Results}

Forced swim test

The effect of tranylcypromine pretreatment on time spent floating, climbing, and swimming in the FST, following nicotine $(0,0.05$, and $0.2 \mathrm{mg} / \mathrm{kg})$, is shown in Fig. 1 . Statistical analysis of floating showed significant effects of tranylcypromine dose $\left(F_{1}, 102=4.6778, p=0.0329\right)$, age $\left(F_{1,102}=8.6648, p=0.0040\right)$, and a nicotine dose $\times$ age interaction $\left(F_{2}, 102=4.0007, p=0.0212\right)$. For adolescents, 
Fig. 1 Nicotine and MAO inhibition effects on FST in adolescent and adult rats. Adult and adolescent rats were tested in the FST $20 \mathrm{~h}$ following tranylcypromine $(3 \mathrm{mg} / \mathrm{kg}$, i.p.) or saline $(1.5 \mathrm{ml} / \mathrm{kg}$, i.p.) pretreatment and $10 \mathrm{~min}$ following saline or nicotine $(0.05$ or $0.2 \mathrm{mg} / \mathrm{kg}$, s.c. $)$ treatment. A synergistic action of tranylcypromine pretreatment and nicotine $(0.2 \mathrm{mg} / \mathrm{kg})$ treatment induced an antidepressant-like effect in adolescent. ${ }^{*} p<0.05$ versus saline-saline; $* * p<0.01$ versus saline-nicotine $0.05 \mathrm{mg} / \mathrm{kg}$, and tranylcypromine-nicotine $0.05 \mathrm{mg} / \mathrm{kg} ; * * * p<0.001$ versus saline-nicotine $0.2 \mathrm{mg} / \mathrm{kg}$; $\# p<$ 0.05 versus saline-nicotine $0.05 \mathrm{mg} / \mathrm{kg}$ and tranylcypromine-nicotine $0.05 \mathrm{mg} / \mathrm{kg}$; \#\#p<0.01 versus saline-nicotine $0.2 \mathrm{mg} / \mathrm{kg}$. In adults, nicotine $0.2 \mathrm{mg} / \mathrm{kg}$ i.p. induces a significant antidepressant-like effect. ${ }^{*} p<0.05 ; * * p<0.01$ versus saline-saline. A significant age difference was obtained. $\# \# p<$ 0.05 versus corresponding adolescent group. $n=8$ per group
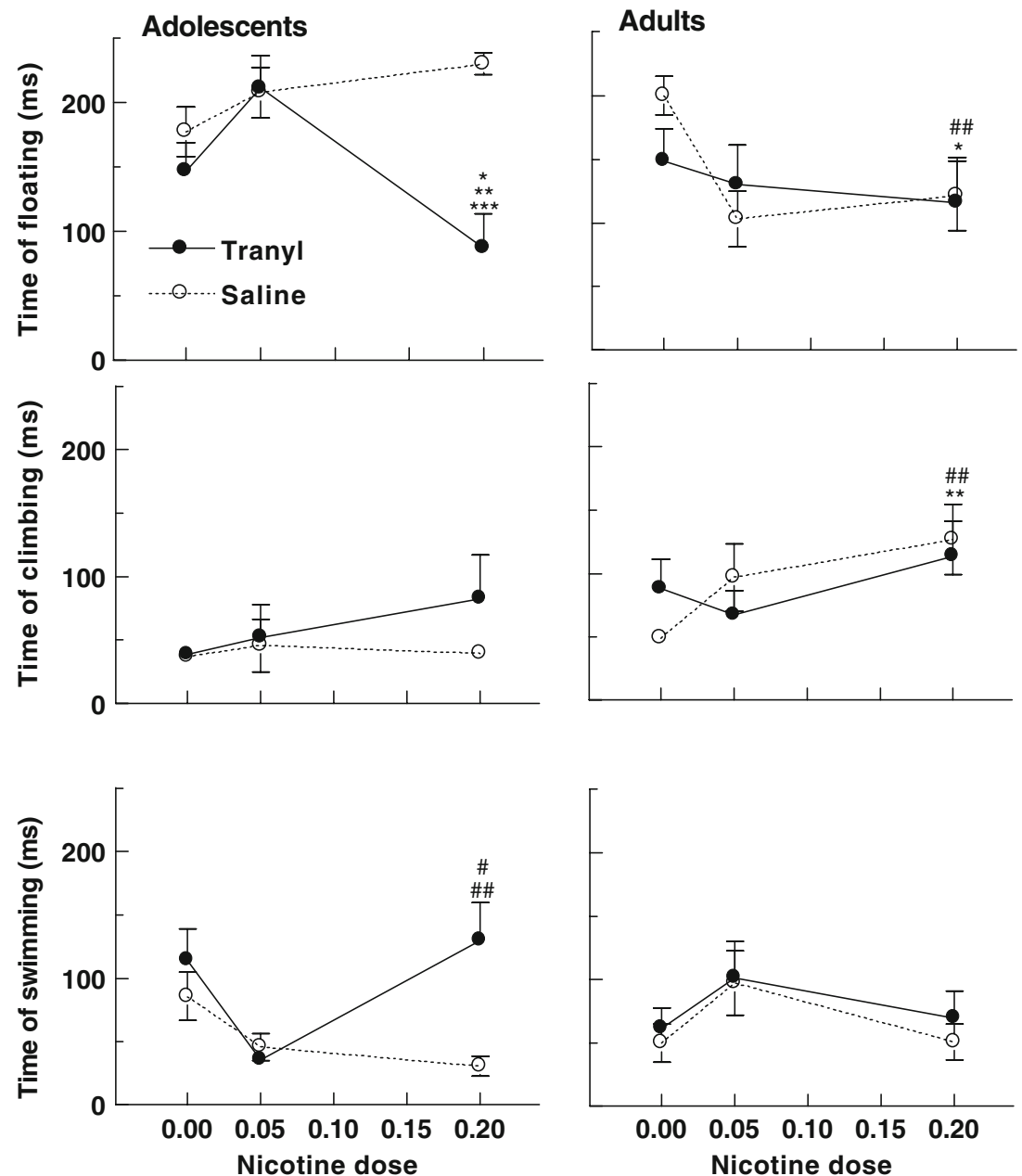

there was a significant effect of tranylcypromine dose $\left(F_{1,47}=10.3438, p=0.0024\right)$, nicotine dose $\left(F_{2,47}=3.2376\right.$, $p=0.0482)$, and a tranylcypromine $\times$ nicotine dose interaction $\left(F_{2,47}=5.8740, p=0.0053\right)$. Post hoc tests showed that floating was significantly decreased following nicotine $(0.2 \mathrm{mg} / \mathrm{kg})$ in tranylcypromine-pretreated as compared to saline-pretreated adolescents ( $p=0.0002$; Fig. 1). In adults, there was a significant effect of nicotine dose $\left(F_{2,57}=3.87\right.$, $p=0.027)$. Post hoc tests showed that floating time in adults treated with nicotine $(0.2 \mathrm{mg} / \mathrm{kg})$ was significantly reduced when compared to the saline adult group $(p=0.03)$. Comparison of floating behavior in saline-pretreated rats only showed a significant age effect $\left(F_{1,53}=13.5119, p=\right.$ $0.0006)$ and age $\times$ nicotine dose interaction $\left(F_{2,53}=7.2051\right.$, $p=0.0017)$. Post hoc Bonferroni corrected $t$ tests showed that floating in adult following nicotine $(0.2 \mathrm{mg} / \mathrm{kg})$ was significantly reduced when compared to the same dose in adolescents ( $p=0.007$; Fig. 1 ).

Statistical analysis of climbing behavior showed significant effects of age $\left(F_{1,102}=12.3444, p=0.0007\right)$ and nicotine dose
$\left(F_{2,102}=3.3781, p=0.0380\right)$, while no significant tranylcypromine effect was found ( $p>0.0712$; Fig. 1). Whereas nicotine had no significant effect on climbing behavior in adolescents, there was a significant effect of nicotine dose $\left(F_{2,54}=3.124, p=0.05\right)$ in adults. Post hoc analysis showed that climbing was significantly higher in salinepretreated adults following nicotine $(0.2 \mathrm{mg} / \mathrm{kg})$ injection as compared to saline injection $(p=0.019)$. Climbing induced by nicotine $(0.2 \mathrm{mg} / \mathrm{kg})$ in saline-pretreated adults was significantly higher than in saline-pretreated adolescents $(p=0.02$; Fig. 1$)$.

Statistical analysis of swimming showed significant tranylcypromine dose effect $\left(F_{1,102}=4.5219, p=0.0359\right)$ and a nicotine dose $\times$ age interaction $\left(F_{2},{ }_{102}=6.6149\right.$, $p=0.002)$. In adolescents, significant effects of tranylcypromine dose $\left(F_{1,47}=5.6764, p=0.0213\right)$, nicotine dose $\left(F_{2}, 47=4.4925, p=0.0164\right)$, and a tranylcypromine $\times$ nicotine dose interaction $\left(F_{2}, 47=3.4228, p=0.0409\right)$ were found in adolescents, whereas none of these effects were significant in adults $(p>0.0960)$. Post hoc Dunnett-corrected 
$t$ test showed that nicotine $(0.2 \mathrm{mg} / \mathrm{kg})$ significantly increased swimming in tranylcypromine-pretreated adolescents as compared to saline pretreated $(p=0.0070$; Fig. 1).

\section{Elevated plus maze}

The effect of nicotine $(0,0.05$, and $0.2 \mathrm{mg} / \mathrm{kg})$ on the percentage of time spent in the open arm of the EPM is presented Fig. 2. As no significant tranylcypromine dose effect was found $\left(F_{1}, 95=0.0835, p=0.7733\right)$, data from tranylcypromine- and saline-pretreated groups were combined. ANOVA showed an overall nicotine dose effect $\left(F_{2}, 101=4.6955, p=0.0112\right)$ and a significant age effect $\left(F_{1}, 101=4.3854, p=0.0388\right)$. Nicotine dose effect was significant in adults $\left(F_{2,46}=4.4446, p=0.0172\right)$ but not in adolescents $\left(F_{2}, 55=0.8780, p=0.4214\right)$. Post hoc adjusted Dunnett comparison showed that, in adults, nicotine $(0.2 \mathrm{mg} / \mathrm{kg})$ significantly increased the time spent in the open arm when compared to saline and nicotine $0.05 \mathrm{mg} / \mathrm{kg}(p<0.0493)$. Furthermore, the time spent in the open arm following nicotine $(0.05 \mathrm{mg} / \mathrm{kg})$ was significantly higher in adolescent than in adults $(p=$ 0.0007; Fig. 2). No effect of nicotine and tranylcypromine was found on the percentage of open arm entries, total arm entries, and total arm time ( $p>0.5$; Table 1).

\section{Ambulatory distance and center time}

The effect of nicotine $(0.2 \mathrm{mg} / \mathrm{kg})$, tranylcypromine $(3 \mathrm{mg} / \mathrm{kg})$, and their combination on ambulatory distance and percentage of time spent in the center of the open field is presented in Fig. 3a, b. For ambulatory distance, ANOVA showed a significant effect of nicotine dose $\left(F_{1,53}=16.1765, p=\right.$

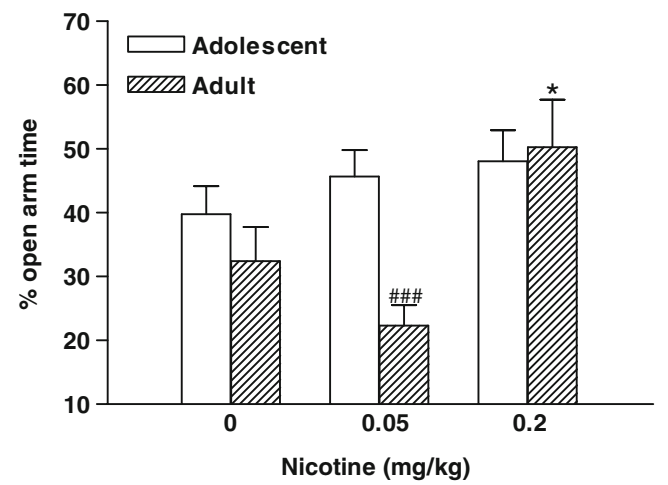

Fig. 2 Effect of nicotine and MAO inhibition on the percentage time spent in the open arm of the EPM. Adult and adolescent rats were tested in the EPM $20 \mathrm{~h}$ following tranylcypromine $(3 \mathrm{mg} / \mathrm{kg}$, i.p.) or saline $(1.5 \mathrm{ml} / \mathrm{kg}$, i.p.) and $10 \mathrm{~min}$ following nicotine $(0.05$, $0.2 \mathrm{mg} / \mathrm{kg}$, s.c.) or saline $(0.75 \mathrm{ml} / \mathrm{kg}$, s.c.). As no effect of MAO inhibition was found, data from saline- and tranylcyprominepretreated groups were combined. ${ }^{*} p<0.05$ versus adult saline and adult nicotine $0.05 \mathrm{mg} / \mathrm{kg}$; \#\#\#p<0.001 versus corresponding adolescent. $n=10-22$ per group
0.0002), tranylcypromine dose $\left(F_{1,53}=18.1271, p=0.0001\right)$, age $\left(F_{1}, 53=8.5497, p=0.0051\right)$, and age $\times$ nicotine dose interaction $\left(F_{1,53}=10.8377, p=0.0018\right.$; Fig. 3a). Moreover, a significant effect of time $\left(F_{2,106}=155.4711, p=0.0000\right)$ and interactions of time $\times$ age $\left(F_{2,106}=4.6865, p=0.0112\right)$, time $\times$ nicotine dose $\times$ age $\left(F_{2,106}=16.3704, p=0.0000\right)$, and time $\times$ nicotine dose $\times$ tranylcypromine dose $\times$ age $\left(F_{2},{ }_{106}=4.0482\right.$, $p=0.0202$ ) were found.

In adolescents, ANOVA showed a significant time effect $\left(F_{2}, \quad 56=92.9693, p=0.0000\right)$ and time $\times$ nicotine dose interaction $\left(F_{2}, 56=5.5801, p=0.0062\right)$. Post hoc Dunnettcorrected $t$ tests showed that ambulatory distance following nicotine injection in tranylcypromine-pretreated adolescents was significantly higher than following saline injection at $t=10 \min (p=0.0005)$ and $t=20 \min (p=0.0149)$. In adults, a significant effect of time $\left(F_{2,50}=67.2110, p=0.000\right)$ and interactions of time $\times$ nicotine dose $\left(F_{2}, 50=12.6741, p=\right.$ $0.000)$ and time $\times$ nicotine dose $\times$ tranylcypromine dose $\left(F_{2,50}=3.7292, p=0.0309\right)$ were found. Post hoc Dunnettcorrected $t$ tests showed that ambulatory distance following saline injection in tranylcypromine-pretreated adults was significantly higher than the three other groups at $t=10 \mathrm{~min}$ $(p<0.0311)$ and than following saline injection in the saline-pretreated group at $t=20 \mathrm{~min}(p=0.0258)$. Moreover, ambulatory distance following nicotine injection in tranylcypromine-pretreated adults was significantly higher than following saline injection in the saline-pretreated group at $t=20 \min (p=0.0258)$ and than the three other groups at $t=30 \min (p<0.0024)$.

Percentage of time spent in the central part of the arena is considered as a measure of stress-induced inhibition of exploration behavior. ANOVA showed a significant effect of age $\left(F_{1,52}=138.3624, p=0.000\right)$, tranylcypromine dose $\left(F_{1,52}=8.3402, p=0.0056\right)$, and a tranylcypromine dose $\times$ age interaction $\left(F_{1,52}=8.5177, p=0.0052\right.$; Fig. $\left.3 b\right)$. Moreover, a significant effect of time $\left(F_{2,104}=3.3992, p=\right.$ $0.0372)$ and interactions of time $\times$ nicotine dose $\left(F_{2,104}=\right.$ $6.0764, p=0.0032)$, time $\times$ age $\left(F_{2,104}=3.4760, p=0.0346\right)$, time $\times$ nicotine dose $\times$ tranylcypromine dose $\times$ age $\left(F_{2}, 104=\right.$ 4.9435, $p=0.0089$ ), time $\times$ nicotine dose $\times$ tranylcypromine dose $\left(F_{2}, \quad 104=4.8922, p=0.0093\right)$, and time $\times$ nicotine dose $\times$ age $\left(F_{2}, 104=6.0628, p=0.0032\right)$ were found. No significant drug effects were observed in adolescents whereas, in adults, there were significant effects of time $\left(F_{2,50}=3.1991, p=0.0493\right)$, tranylcypromine dose $\left(F_{1,25}=\right.$ 7.8505, $p=0.0097$ ), and interactions of time $\times$ nicotine dose $\left(F_{2}, 50=5.6504, p=0.0061\right)$ and time $\times$ nicotine dose $\times$ tranylcypromine dose $\left(F_{2,50}=4.5783, p=0.0149\right.$; Fig. 3b). Post hoc Dunnett-corrected $t$ tests showed that the time spent in the center space following nicotine injection in tranylcypromine-pretreated adults was significantly higher than the three other groups at $t=30 \mathrm{~min}(p<0.0223$; Fig. 3b). 
Table 1 Effects of nicotine and MAO inhibition in the EPM test in adolescent and adult rats

Results are expressed as means \pm SEM. $n=10-22$ per group

\begin{tabular}{lllll}
\hline Age & Tranyl-nico dose $(\mathrm{mg} / \mathrm{kg})$ & $\%$ Open arm entries & Total arm entries & Total arm time \\
\hline Adult & sal-sal & $38.13 \pm 6.349$ & $19.73 \pm 5.466$ & $172.6 \pm 6.384$ \\
Adolescent & sal-sal & $42.91 \pm 6.001$ & $17.44 \pm 1.692$ & $165.8 \pm 9.451$ \\
Adult & sal-nico0.05 & $29.48 \pm 5.975$ & $14 \pm 1.673$ & $171 \pm 21$ \\
Adolescent & sal-nico0.05 & $41.31 \pm 5.921$ & $19.89 \pm 1.359$ & $171.3 \pm 11.44$ \\
Adult & sal-nico0.2 & $47.69 \pm 11.26$ & $19.63 \pm 4.242$ & $175.8 \pm 13.78$ \\
Adolescent & sal-nico0.2 & $36.64 \pm 2.707$ & $21 \pm 0.9888$ & $158.6 \pm 8.308$ \\
Adult & tranyl3-sal & $41.24 \pm 3.886$ & $15.5 \pm 1.098$ & $171.2 \pm 9.013$ \\
Adolescent & tranyl3-sal & $34.78 \pm 5.762$ & $18.56 \pm 1.345$ & $153 \pm 13.16$ \\
Adult & trany13-nico0.05 & $26.27 \pm 4.255$ & $20 \pm 1.581$ & $171.6 \pm 4.027$ \\
Adolescent & tranyl3-nico0.05 & $42.24 \pm 2.915$ & $23.78 \pm 1.906$ & $184.6 \pm 8.499$ \\
Adult & tranyl3-nico0.02 & $41.25 \pm 8.212$ & $26.6 \pm 7.218$ & $161.1 \pm 12.89$ \\
Adolescent & tranyl3-nico0.02 & $50.18 \pm 6.567$ & $22.75 \pm 1.28$ & $170.4 \pm 8.951$ \\
\hline
\end{tabular}

\section{Discussion}

Whereas tobacco smoke contains over 4,000 constituents (Report 1989; Lewis et al. 2007), most experimental analyses of smoking with animal models examine the effects of nicotine alone. Given the prominent inhibition of MAO activity in the brains and periphery of smokers (Fowler et al. 1996a, b, 2003), the present study was designed to assess possible synergistic interactions between nicotine and MAO inhibition on depression- and anxietyrelated behaviors in adolescent and adult rats. Since the irreversible MAO inhibitor in tobacco smoke has not yet been structurally characterized (Lewis et al. 2007), we used tranylcypromine $(3 \mathrm{mg} / \mathrm{kg})$, a clinical irreversible inhibitor of MAO-A and MAO-B, to inhibit MAO activity prior to nicotine treatment. Pretreatment with this MAO inhibitor has previously been shown to increase the reinforcing effects of nicotine in both adult and adolescent rats (Villégier et al. 2007). Given prior observations that tranylcypromine has acute effects that are unrelated to MAO inhibition (Baker et al. 1992; Villégier et al. 2007), animals were pretreated with the MAO inhibitor $20 \mathrm{~h}$ prior to behavioral testing. We have previously shown that MAO-A and MAO-B activity remains inhibited by approximately $70 \%$ and $85 \%$, respectively, $20 \mathrm{~h}$ after tranylcypromine pretreatment (Villégier et al. 2007). This is somewhat greater than the $40 \%$ to $50 \%$ decrease seen in the brains of smokers (Fowler et al. 1996a, b).

Assessment of mood-related behaviors in animals is complex and open to multiple interpretations (Cryan et al.
Fig. 3 Effect of nicotine and MAO inhibition on a ambulatory distance and $\mathbf{b}$ center time. Adult and adolescent rats were tested in the open field $20 \mathrm{~h}$ following tranylcypromine $(3 \mathrm{mg} / \mathrm{kg}$, i.p.) or saline $(1.5 \mathrm{ml} / \mathrm{kg}$, i.p. $)$ and 10 min following nicotine $(0.2 \mathrm{mg} / \mathrm{kg}$, s.c. $)$ or saline $(0.75 \mathrm{ml} / \mathrm{kg}$, s.c.). Ambulatory distance was significantly increased in both adults and adolescents by tranylcypromine and nicotine. ${ }^{*} p<0.05 ;{ }^{* *} p<0.01$ versus corresponding saline. Time spent in the center area of the open field was significantly increased in adults following nicotine and tranylcypromine pretreatment. ${ }^{*} p<0.05$ versus the other treatments. $n=8$ per group
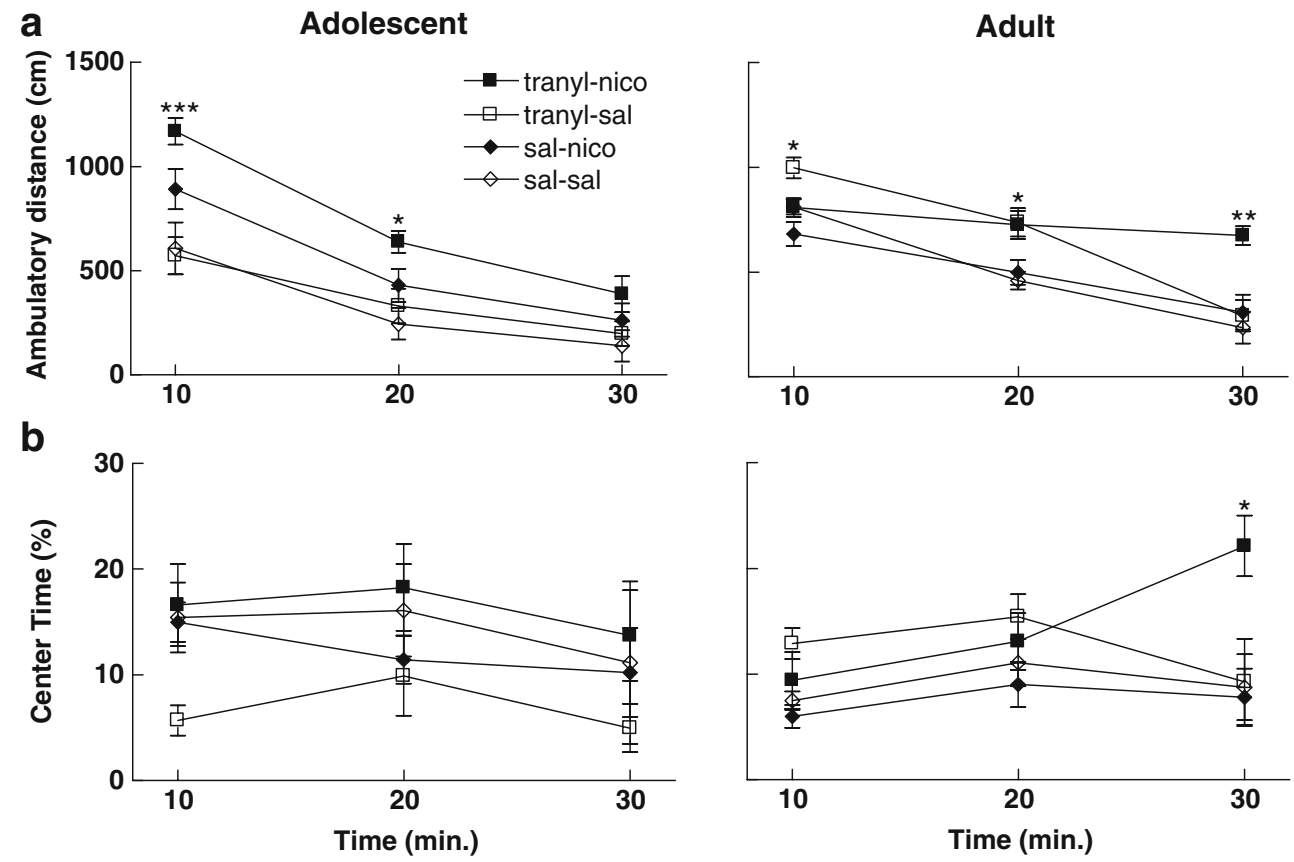
2002a; Ramos 2008). We have used two common tests of anxiety-related behavior, the open field test and the EPM. These tests have been shown to measure different aspects of emotionality (reviewed by Ramos 2008). The FST has been widely used to measure depressive-like behavioral states in animals (Overstreet 1993; Lucki 1997; Cryan et al. 2002a). Although these tests have been critiqued for showing immediate responses to antidepressant drugs, when clinical findings require longer exposure, it has been shown that more potent effects are obtained in this test when drug exposure is chronic (Cryan et al. 2005). For the present study, we chose not to do long-term exposure to nicotine and tranylcypromine since this drug combination has been shown to increase in psychostimulant efficacy with repeated drug exposure (Villégier et al. 2003).

\section{Behavioral effects of nicotine alone}

Nicotine alone had no significant behavioral effect in adolescent rats. In contrast, nicotine $(0.2 \mathrm{mg} / \mathrm{kg})$ significantly decreased floating time and increased climbing time in the FST in adult rats. This phenomenon was dissociated from any stimulant effect on locomotor activity. Floating response, or immobility, remains a widely used tool to evaluate "behavioral despair". A decrease in immobility and increased climbing, as was seen in this study, is associated with increased noradrenergic activity in the ventral bundle pathway from brainstem nuclei (Cryan et al. 2002a, b). This behavioral response may result from a direct nicotine activation of brainstem noradrenergic nuclei, which we have previously shown to express nicotinic receptor subunit mRNAs in an age-dependent manner (O'Leary et al. 2008). Our behavioral findings are also consistent with prior studies in adult rats in which the same dose $(0.2 \mathrm{mg} / \mathrm{kg})$ and a higher dose $(0.4 \mathrm{mg} / \mathrm{kg})$ of nicotine yielded comparable results, i.e., an antidepressant-like effect of nicotine that was dissociable from its effects on locomotor activity (Tizabi et al. 1999; Vazquez-Palacios et al. 2004, 2005). Future studies should examine whether these effects are mediated by noradrenergic activation.

In parallel, we report that nicotine $(0.2 \mathrm{mg} / \mathrm{kg})$ increases the time spent in the open arm of the EPM by adult rats. As EPM is an established animal model of anxiety-like behavior (Hogg 1996), used to evaluate panic and generalized anxiety disorder (Cheeta et al. 2000), the present data indicate an alleviation of an anxiety-like state. A lower dose of nicotine $(0.05 \mathrm{mg} / \mathrm{kg})$ induced a trend toward decreased time spent in the open arm which, although not significantly different from saline-treated adults, was significantly different from adolescents treated with the same nicotine dose. Nicotine has been previously reported to present bimodal effects on anxiety, showing both anxiolytic and anxiogenic effects in animal tests (File et al. 1998; Irvine et al. 1999; Ouagazzal et al. 1999; Cheeta et al. 2000; Kenny et al. 2000). The response to nicotine is dependent on experimental conditions, including the period of drug exposure (withdrawal, acute or chronic administration, prenatal; Slawecki et al. 2005), drug doses, and the behavioral paradigm used to assess anxiety-related behavior (Tucci et al. 2003; Ouagazzal et al. 1999; Marco et al. 2005). As shown by the present study, nicotine's effect on anxiety is also dependent on the model used to measure anxiety. We used the open field to measure both anxiety-like behaviors and locomotor activity (Prut and Belzung 2003). Because the animal is separated from its social group and that the arena is very large relative to the animal's breeding or natural environment, the open field is considered to measure reaction to a stressful event. In both adults and adolescents, nicotine had no effect on ambulatory distance or stress-induced inhibition of exploratory behavior. This finding is different from that found previously, where an intravenous injection of nicotine increased locomotor activity in juveniles but decreased it in adults, while center time was increased at both ages (Cao et al. 2007). Nicotine doses and route of administration may explain these differing results.

\section{Behavioral effects of nicotine and tranylcypromine}

Tranylcypromine alone had no effect on either depressionor anxiety-like behavior in adult and adolescent rats, when given $20 \mathrm{~h}$ prior to testing. In contrast, tranylcypromine pretreatment given $1 \mathrm{~h}$ prior to FST significantly decreased floating and increased climbing in adult rats (data not shown), consistent with prior literature findings with MAO inhibitors (Cryan et al. 2005; Shimazu et al. 2005). A significant stimulant effect of tranylcypromine pretreatment on locomotion was seen in adult rats, but not adolescents, during open-field testing. This may be due to a differential sensitivity to MAO inhibition of response to novelty at the two different ages, with adults being more sensitive than juvenile rats.

Whereas several prior studies have assessed nicotine effects on depression- and anxiety-related behavior (File et al. 1998; Irvine et al. 1999; Ouagazzal et al. 1999; Tizabi et al. 1999; Cheeta et al. 2000; Kenny et al. 2000; VazquezPalacios et al. 2004, 2005), the present is the first to combine nicotine and MAO inhibition. Whereas nicotine had no effect on saline-pretreated adolescents, it significantly reduced floating and increased swimming in the FST when combined with tranylcypromine pretreatment. This is consistent with an antidepressant-like effect of this drug combination, mediated via activation of serotonergic mechanisms (Cryan et al. 2002a). Since the drug combination did enhance locomotor activity in adolescent animals, a spurious psychostimulant effect cannot be completely ruled 
out as an explanation for these findings. However, this seems unlikely since the psychostimulant effect of tranylcypromine alone in adults was not associated with behavioral changes in the FST. Another explanation is a reduced aversive response to an explicitly negative environment, as has been shown previously in adult rats (Vale and Balfour 1989). Given the complexities of interpretation of these data, further studies are warranted to determine whether nicotine mitigates depressive behavior in adolescents when combined with MAO inhibition. Possible regulation of serotonergic systems should also be examined as a mechanism underlying the enhanced swimming. Prior studies have shown direct cholinergic modulation of serotonergic cells in the dorsal raphe via nicotinic receptor activation (Galindo-Charles et al. 2008). Nicotine has also been reported to have complex effects on serotonergic transmission in both juvenile and adult brain (Engberg et al. 2000; Li et al. 1998).

One other significant effect of the nicotine/tranylcypromine combination was a significant increase in the percentage time spent in the center of the open field by adults. Although there was a corresponding increase in locomotor activity, this is unlikely to underlie the increased exploration of the center field since this did not occur at an earlier time point when psychostimulant effects of tranylcypromine alone were observed. Nor did increased center time accompany the psychostimulant response to nicotine/ tranylcypromine combination seen in adolescents. These data afford further support for a synergistic action between nicotine and MAO inhibitors, as has been described previously for self-administration and behavioral sensitization (Villégier et al. 2003, 2005, 2007).

\section{Conclusion}

The present study shows that the effects of nicotine on mood-related behaviors are highly dependent on age. These findings are consistent with prior behavioral and neurochemical studies showing substantial age differences in response to nicotine (reviewed by Dwyer et al. 2009). We now show that the effects of MAO inhibition are similarly age dependent. In particular, adolescents treated with the combination of nicotine and MAO inhibitor show an acute psychostimulant response and decreased depressive-like behavior, in contrast to adults. Such findings emphasize the need to consider both age and the influence of other tobacco smoke constituents when using animal models to establish mechanisms underlying smoking behavior.

Acknowledgments This work was supported by a fellowship from PHS Grant DA19138 and DA21267. Experiments comply with the current laws of the country in which they were performed. All experimental procedures were performed in compliance with $\mathrm{NIH}$ Guide for Care and Use of Laboratory Animals (NIH no. 85-23, rev. 1985) and approved by the UCI Institutional Animal Care and Use Committee.

Open Access This article is distributed under the terms of the Creative Commons Attribution Noncommercial License which permits any noncommercial use, distribution, and reproduction in any medium, provided the original author(s) and source are credited.

\section{References}

Baker GB, Coutts RT, McKenna KF, Sherry-McKenna RL (1992) Insights into the mechanisms of action of the MAO inhibitors phenelzine and tranylcypromine: a review. J Psychiatry Neurosci $17: 206-214$

Balfour D, Benowitz N, Fagerstrom K, Kunze M, Keil U (2000) Diagnosis and treatment of nicotine dependence with emphasis on nicotine replacement therapy. A status report. Eur Heart J 21:438-445

Breslau N, Novak SP, Kessler RC (2004) Psychiatric disorders and stages of smoking. Biol Psychiatry 55:69-76

Cao J, Belluzzi JD, Loughlin SE, Keyler DE, Pentel PR, Leslie FM (2007) Acetaldehyde a major constituent of tobacco smoke enhances behavioral endocrine and neuronal responses to nicotine in adolescent and adult rats. Neuropsychopharmacology 32:20252035

Cheeta S, Kenny PJ, File SE (2000) Hippocampal and septal injections of nicotine and 8-OH-DPAT distinguish among different animal tests of anxiety. Prog Neuropsychopharmacol Biol Psychiatry 24:10531067

Cryan JF, Markou A, Lucki I (2002a) Assessing antidepressant activity in rodents: recent developments and future needs. Trends Pharmacol Sci 23(5):238-245

Cryan JF, Page ME, Lucki I (2002b) Noradrenergic lesions differentially alter the antidepressant-like effects of reboxetine in a modified forced swim test. Eur J Pharmacol 436:197-205

Cryan JF, Page ME, Lucki I (2005) Differential behavioral effects of the antidepressants reboxetine fluoxetine and moclobemide in a modified forced swim test following chronic treatment. Psychopharmacology (Berl) 182:335-344

Daniels WM, Pietersen CY, Carstens ME, Stein DJ (2004) Maternal separation in rats leads to anxiety-like behavior and a blunted ACTH response and altered neurotransmitter levels in response to a subsequent stressor. Metab Brain Dis 19:3-14

Dwyer JB, McQuown SC, Leslie FM (2009) The dynamic effects of nicotine on the developing brain. Pharmacol Ther 122:125139

Engberg G, Erhardt S, Sharp T, Hajos M (2000) Nicotine inhibits firing activity of dorsal raphe 5-HT neurones in vivo. Naunyn Schmiedebergs Arch Pharmacol 362:41-45

Fergusson DM, Lynskey MT, Horwood LJ (1996) Comorbidity between depressive disorders and nicotine dependence in a cohort of 16-year-olds. Arch Gen Psychiatr 53:1043-1047

File SE, Kenny PJ, Ouagazzal AM (1998) Bimodal modulation by nicotine of anxiety in the social interaction test: role of the dorsal hippocampus. Behav Neurosci 112:1423-1429

Fowler JS, Volkow ND, Wang GJ, Pappas N, Logan J, MacGregor R, Alexoff D, Shea C, Schlyer D, Wolf AP, Warner D, Zezulkova I, Cilento R (1996a) Inhibition of monoamine oxidase B in the brains of smokers. Nature 379:733-736

Fowler JS, Volkow ND, Wang GJ, Pappas N, Logan J, Shea C, Alexoff D, MacGregor RR, Schlyer DJ, Zezulkova I, Wolf AP 
(1996b) Brain monoamine oxidase A inhibition in cigarette smokers. Proc Natl Acad Sci U S A 93:14065-14069

Fowler JS, Logan J, Wang GJ, Volkow ND (2003) Monoamine oxidase and cigarette smoking. Neurotoxicology 24:75-82

Galindo-Charles L, Hernandez-Lopez S, Galarraga E, Tapia D, Bargas J, Garduño J, Frías-Dominguez C, Drucker-Colin R, Mihailescu S (2008) Serotoninergic dorsal raphe neurons possess functional postsynaptic nicotinic acetylcholine receptors. Synapse 62:601-615

Hogg S (1996) A review of the validity and variability of the elevated plus-maze as an animal model of anxiety. Pharmacol Biochem Behav 54:21-30

Irvine EE, Cheeta S, File SE (1999) Time-course of changes in the social interaction test of anxiety following acute and chronic administration of nicotine. Behav Pharmacol 10:691-697

Kenny PJ, Cheeta S, File SE (2000) Anxiogenic effects of nicotine in the dorsal hippocampus are mediated by 5-HT1A and not by muscarinic M1 receptors. Neuropharmacology 39:300-307

Khantzian EJ (1997) The self-medication hypothesis of substance use disorders: a reconsideration and recent applications. Harv Rev Psychiatry 4:231-244

Lasser K, Boyd JW, Woolhandler S, Himmelstein DU, McCormick D, Bor DH (2000) Smoking and mental illness: a population-based prevalence study. Jama 284:2606-2610

Laviola G, Macri S, Morley-Fletcher S, Adriani W (2003) Risk-taking behavior in adolescent mice: psychobiological determinants and early epigenetic influence. Neurosci Biobehav Rev 27:19-31

Lewis A, Miller JH, Lea RA (2007) Monoamine oxidase and tobacco dependence. Neurotoxicology 28:182-195

Li X, Rainnie DG, McCarley RW, Greene RW (1998) Presynaptic nicotinic receptors facilitate monoaminergic transmission. J Neurosci 18:1904-1912

Lucki I (1997) The forced swimming test as a model for core and component behavioral effects of antidepressant drugs. Behav Pharmacol 8:523-532

Marco EM, Llorente R, Perez-Alvarez L, Moreno E, Guaza C, Viveros MP (2005) The kappa-opioid receptor is involved in the stimulating effect of nicotine on adrenocortical activity but not in nicotine induced anxiety. Behav Brain Res 163:212-218

Morris CD, Giese AA, Turnbull JJ, Dickinson M, Johnson-Nagel N (2006) Predictors of tobacco use among persons with mental illnesses in a statewide population. Psychiatr Serv 57:1035-1038

O'Leary KT, Loughlin SE, Chen Y, Leslie FM (2008) Nicotinic acetylcholine receptor subunit mRNA expression in adult and developing rat medullary catecholamine neurons. J Comp Neurol 510:655-672

Ouagazzal AM, Kenny PJ, File SE (1999) Modulation of behaviour on trials 1 and 2 in the elevated plus-maze test of anxiety after systemic and hippocampal administration of nicotine. Psychopharmacology (Berl) 144:54-60

Overstreet DH (1993) The Flinders sensitive line rats: a genetic animal model of depression. Neurosci Biobehav Rev 17:51-68

Poirier MF, Canceil O, Bayle F, Millet B, Bourdel MC, Moatti C, Olie JP, Attar-Levy D (2002) Prevalence of smoking in psychiatric patients. Prog Neuropsychopharmacol Biol Psychiatry 26:529-537

Porsolt RD, Le Pichon M, Jalfre M (1977) Depression: a new animal model sensitive to antidepressant treatments. Nature 266:730 732
Prut L, Belzung C (2003) The open field as a paradigm to measure the effects of drugs on anxiety-like behaviors: a review. Eur J Pharmacol 463:3-33

Ramos A (2008) Animal models of anxiety: do I need multiple tests? Trends Pharmacol Sci 29:493-498

Report USGs (1989) Reducing the health consequences of smoking, chapter 2. USG, Washington, DC, pp 79-92

Salin-Pascual RJ, Drucker-Colin R (1998) A novel effect of nicotine on mood and sleep in major depression. Neuroreport 9:57-60

Shiffman S (1993) Assessing smoking patterns and motives. J Consult Clin Psychol 61:732-742

Shih JC (2004) Cloning after cloning knock-out mice and physiological functions of MAO A and B. Neurotoxicology 25:21-30

Shimazu S, Minami A, Kusumoto H, Yoneda F (2005) Antidepressant-like effects of selegiline in the forced swim test. Eur Neuropsychopharmacol 15:563-571

Slawecki CJ, Thorsell AK, El Khoury A, Mathe AA, Ehlers CL (2005) Increased CRF-like and NPY-like immunoreactivity in adult rats exposed to nicotine during adolescence: relation to anxiety-like and depressive-like behavior. Neuropeptides 39:369377

Snyder M (2006) Serious mental illness and smoking cessation. Issues Ment Health Nurs 27:635-645

Spielberger CD, Jacobs GA (1982) Personality and smoking behavior. J Pers Assess 46:396-403

Tizabi Y, Overstreet DH, Rezvani AH, Louis VA, Clark E Jr, Janowsky DS, Kling MA (1999) Antidepressant effects of nicotine in an animal model of depression. Psychopharmacology (Berl) 142:193-199

Tucci S, Genn RF, Marco E, File SE (2003) Do different mechanisms underlie two anxiogenic effects of systemic nicotine? Behav Pharmacol 14:323-329

Upadhyaya HP, Deas D, Brady KT, Kruesi M (2002) Cigarette smoking and psychiatric comorbidity in children and adolescents. J Am Acad Child Adolesc Psychiatry 41:1294-1305

Vale AL, Balfour DJ (1989) Aversive environmental stimuli as a factor in the psychostimulant response to nicotine. Pharmacol Biochem Behav 32:857-860

Vazquez-Palacios G, Bonilla-Jaime H, Velazquez-Moctezuma J (2004) Antidepressant-like effects of the acute and chronic administration of nicotine in the rat forced swimming test and its interaction with fluoxetine. Pharmacol Biochem Behav 78:165-169

Vazquez-Palacios G, Bonilla-Jaime H, Velazquez-Moctezuma J (2005) Antidepressant effects of nicotine and fluoxetine in an animal model of depression induced by neonatal treatment with clomipramine. Prog Neuropsychopharmacol Biol Psychiatry 29:39-46

Villégier AS, Blanc G, Glowinski J, Tassin JP (2003) Transient behavioral sensitization to nicotine becomes long-lasting with monoamine oxidases inhibitors. Pharmacol Biochem Behav $76: 267-274$

Villégier AS, Salomon L, Granon S, Changeux JP, Belluzzi JD, Leslie FM, Tassin JP (2005) Monoamine oxidase inhibitors allow locomotor and rewarding responses to nicotine. Neuropsychopharmacology 31:1704-1713

Villégier AS, Lotfipour S, McQuown SC, Belluzzi JD, Leslie FM (2007) Tranylcypromine enhancement of nicotine selfadministration. Neuropharmacology 52:1415-1425 